\title{
Osmanlı borçları hakkında İngiliz Lordlar Kamarası'nda yapılan 21 Mayıs 1924 tarihli oturumun incelemesi
}

Çă̆daş YÜKSEL ${ }^{1}$

\begin{abstract}
Özet
Sanayi Devrimi sonrasında zenginleşen Avrupa devletleri 19. yüzyılın ikinci yarısından itibaren ekonomik sıkıntı içindeki ülkelere borç vermeye başlamışlardır. Borçların devamında Avrupa sermayesi bu ülkelere akın etmiş ve ülkeler neredeyse sömürge haline getirilmişlerdir. Osmanlı İmparatorluğu da 1854 yılında Kırım Savaşı'nın getirdiği yük nedeniyle dış borç almak zorunda kalmıştır. Alınan borçlar verimli kullanılmadığı için borç yükü hızla artmıştır. Bu dönemde Avrupa sermayesi Osmanlı topraklarında demiryolu yatırımlarına da başlamıştır. İmparatorluğun dış borç serüveni 1876 yılında mali iflasla sonuçlanmıştır. Borçları ödeyebilmek için Duyun-u Umumiye İdaresi kurulmuştur. Bu kuruluş devlet gelirlerinin bir kısmını kontrolü altına almıştır. Böylece yatırımlarını arttıran Avrupa sermayesi, Duyun-u Umumiye İdaresi ve kapitülasyonlar kısa süre içerisinde Osmanlı İmparatorluğu'nun ekonomik bağımsızlığına son vermişlerdir. Millî Mücadele sonrasında Lozan Antlaşması ile Duyun-u Umumiye İdaresi ve kapitülasyonlar kaldırılmış ve Türkiye Cumhuriyeti'nin tam bağımsızlığı sağlanmıştır. Ancak borçlar meselesi 1928 yılına kadar sorun olmaya devam etmiştir. Bu tarihte yapılan antlaşma ile borç ödemeleri başlamış ve 1954 yılına kadar devam etmiştir.
\end{abstract}

\section{Examination of the session on the Ottoman Debts held at the British House of Lords on 21 May 1924}

\begin{abstract}
European states, enriched after the Industrial Revolution, started to lend money to countries in economic distress from the second half of the 19th century. After the debt, European capital flooded to these countries and the countries were almost colonized. The Ottoman Empire also had to borrow foreign debt due to the burden of the Crimean War in 1854. The debt burden increased rapidly as the borrowed debts were not used efficiently. During this period, European capital also started railway investments in Ottoman lands. The foreign debt adventure of the empire ended in financial bankruptcy in 1876. The Ottoman Public Debt Administration was established to pay debts. This organization controlled some of the state revenues. Thus, European capital that increased their investments, the Ottoman Public Debts Administration and capitulations put an end to the economic independence of the Ottoman Empire in a short time. The Ottoman Public Debt Administration and capitulations removed with Treaty of Lausanne that signed after the National Struggle and thus achieved full of independence of the Republic of Turkey. However, the debt issue continued to be a problem until 1928. With the treaty signed on this date, debt payments started and continued until 1954.
\end{abstract}

Keywords: the Ottoman Empire, European States, the Ottoman Public Debt Administration

${ }^{1}$ Arş. Gör. Dr. Pamukkale Üniversitesi Fen-Edebiyat Fakültesi Tarih Bölümü, cyuksel@pau.edu.tr 


\section{Giriş}

Osmanlı İmparatorluğu ilk dış borcunu 1854 yılında almış ve bu borçların tamamen ödenmesi yüz yıl sürmüştür. Bu borçlanma devleti emperyalist devletlerin sömürü alanı haline getirmiştir. Alınan ilk borçların yüksek faiz ve masrafla elde edilmesi ve verimsiz alanlarda kullanılması borç yükünün hızla artmasına yol açmıştır. Devlet kısa süre içerisinde borçların faizlerini bile ödeyemez duruma düşmüştür. Mali iflas sonrasında Duyun-u Umumiye İdaresi'nin kurulması imparatorluğun ekonomik bağımsızlığına son vermiştir. Bu olay devletin yıkılışını hızlandırmıştır. Milli Mücadele'nin zaferi sonrasında yapılan Lozan Antlaşması ile Duyun-u Umumiye İdaresi kaldırılmış böylece tam bağımsız Türkiye yolunda önemli bir adım atılmıştır. Ancak borçlar meselesi tam olarak çözülememiştir. Bu konuda 1928 yılına kadar müzakereler devam etmiştir. Alacaklılar, İngiltere'de ve Fransa'da politikacılar üzerinde baskı kurarak karlarını koruma çabası içinde olmuşlardır. İngiltere'de bunu sağlamak için Yabancı Tahvil Sahipleri Konseyi kurulmuş ve bazı önemli politikacılar bu konseye üye olmuşlardır. 1924 yılında İngiltere Lordlar Kamarası'nda bu konseyin girişimi ile Osmanlı borçları ve tahvil sahiplerinin durumunu tartışmak üzere bir oturum düzenlenmiştir.

Lordlar Kamarası her ne kadar İngiliz Parlamentosu'nun üst kanadını oluştursa da kararların asıl alındığı merci Avam Kamarası'dır. Osmanlı borçları konusunun Lordlar Kamarası'nda tartışılması aslında hükümetin mevcut yapıda herhangi bir değişiklik yapmaya niyeti olmadığı şeklinde yorumlanabilir. Ancak yine de borç sahipleri siyasete belli oranda nüfuz ederek konunun Lordlar Kamarası'nda da olsa tartışılmasını sağlayabilmişlerdir. Yapılan oturumda konsey üyesi politikacılar İngiliz Hükümeti'ni Osmanlı borçları konusunda sert bir şekilde eleştirmişlerdir. Bu oturumdan konseyin Lozan Antlaşması'ndan memnun olmadığı Duyun-u Umumiye rejimini istediği de anlaşılmaktadır. İngiliz Hükümeti buna karşın yapılan antlaşmayı ve hükümet politikasını savunmuştur. $\mathrm{Bu}$ çalışmada Osmanlı borçları konusunda Lordlar Kamarası'nda yapılan oturum analiz edilmiştir. Bu yapılırken İngiltere Parlamento Arşivi tutanaklarından faydalanılmıştır. İngiltere Parlamento tutanakları belirli aralıklarla basılmaktadır. Bunun yanı sıra tutanaklar günümüzde internet ortamına da aktarılmıştır.

\section{Tarihsel arka plan}

Sanayileşmiş Avrupa devletleri özellikle 1860-1870 yılları arasında zenginliklerinin zirvesini yaşamışlardır (Özdemir, 2009, s. 6). Bu nedenle o dönemde sanayileşememiş pek çok ülkeye önemli ölçüde borç verilmiştir. 1872 yılında yaşanan kriz sonrasında Avrupa sermayesi sanayileşememiş ülkelere doğru yayılmaya ağırlık vermiştir (Fişek, 1967, s. 157). Bu dönemde Osmanlı İmparatorluğu Batı'dan ilk kez 1854 yılında borç almak zorunda kalmıştır (Kartopu, 2012, s. 32). 1856 yılında ise Osmanlı topraklarına ilk demiryolu yatırımı yapılmıştır (Fişek, 1967, s. 160). Böylece Osmanlı İmparatorluğu İngiltere ve Fransa'nın mali kontrolü altına girmeye başlamıştır.

Osmanlı İmparatorluğu'nu borç almaya götüren süreç çok daha önceki tarihlerde başlamıştır. Coğrafi keşifler sonrasında dünya ticaretinin okyanuslar üzerinden yapılması hız kazanmıştır. Bu durum Osmanlı İmparatorluğu gibi geleneksel ticaret yollarına hakim olan devletlerin gelirlerinin azalmasına neden olmuştur. Avrupa Devletleri'nin Amerika'dan yağmalayarak getirdikleri gümüşün Avrupa ve Osmanlı piyasalarını alt üst etmesi de Osmanlı maliyesi için ciddi bir sorun teşkil etmiştir (Kodaman, 2007, s. 13). 18. ve 19. yüzyıllarda toprak kayıplarının gittikçe artması Osmanlı İmparatorluğu'nda vergi gelirlerinin gittikçe azalmasına yol açmıştır (Y1lmaz, 2002, s. 188). Savaşların artması ve uzaması askeri harcamaların yükselmesine neden olmuştur. Bu dönemde devlet vergileri başarılı şekilde toplamakta zorlanmıştır (Ergüder, 2020, s. 473). Kapitülasyonların varlığı ise devletin gümrük gelirlerini önemli ölçüde düşürmüsşür (Kazgan, 1999, s. 26)). Böylelikle imparatorluğun masrafları gittikçe artarken gelirleri giderek azalmıştır (Pamuk, 1984, s. 55). 19. yüzyıl boyunca Batı devletleri ile yapılan ticaret antlaşmaları da Osmanlı ekonomisinin çökmesinde önemli rol oynamışlardır. 1838 yılında İngiltere ile yapılan Balta Limanı ve 1840 yılında diğer devletlerle yapılan ticaret antlaşmaları sonrasında Osmanlı ekonomisi zarar görmüş ve imparatorluğun gelirleri önemli ölçüde düşmüştür (Yıldız, 2011, s. 319). Bu antlaşmalar sonrasında Batı malları Osmanlı pazarını istila etmiş ve yerli sanayinin kurulması imkansız hale gelmiştir (Özdemir, 2009, s. 7). Antlaşmalar bir bakıma kapitülasyonları daha ileri seviyeye taşımışlardır. 
18. yüzyılın sonlarında savaşlarda alınan mağlubiyetler ve ödenen tazminatlar nedeniyle Osmanlı maliyesi büyük bir kriz ile karşı karşıya kalmıştır. 1787 yılında Rusya ile savaş başladığında Osmanlı yönetimi savaş masraflarını karşılayabilmek için devlet iç borçlanma yoluna gitmiş fakat istediği kadar para toplayamamıştır. Bunun üzerine Hollanda ve İspanya'dan borç almaya çalışmış ancak bir anlaşma sağlayamamıştır (Arslan, 2015, s. 2). II. Mahmut döneminde ise ilişkilerin iyi olduğu İngiltere'den borç alınması gündeme gelmiştir. Fakat yapılan görüşmelerden bir sonuç elde edilememiştir (Karamursal, 1989, s. 15). Bu nedenle Osmanlı İmparatorluğu uzun süre diş borç olmadan yaşamaya çalışmıştır. Krizlerin iç borçlanma yolu ile atlatılması için yoğun çaba gösterilmiştir (Pamuk, 1999, s. 186). Ancak 1850'li yıllarda Osmanlı hazinesi artık askeri masraflar ve maaş ödemeleri gibi zorunlu ihtiyaçları bile karşılayamaz hale gelmiştir (Müderrisoğlu, 1990, s. 98). Bunun üzerine Sadrazam Mustafa Reşit Paşa Paris ve Londra bankalarıyla görüşmeler yapmış ve 55 milyon franklık bir borç antlaşması imzalamıştır. Kamuoyu tepkisi sonrasında sadrazam görevden alınmış ve Osmanlı İmparatorluğu 2.2 milyon lira tazminat ödemek zorunda kalmıştır (Küçük-Ertüzün, 1994, s. 58).

Osmanlı İmparatorluğu ile Rusya arasında yaşanan mücadeleye Batı devletlerinin de dahil olması neticesinde 1853 yılında Kırım Savaşı patlak vermiştir (Acar, 2019, s. 114). Kutsal yerler sorunu nedeniyle patlak veren savaşta İngiltere ve Fransa Osmanlı'nın yanında yer alarak Rusya'ya karşı savaşmışlardır (Birbudak, 2018, s. 244). Bunun yanı sıra pek çok Avrupalı da Osmanlı Ordusu'nda görev yapmıştır. Özellikle sağlık alanında İngiliz ve Fransızlardan önemli ölçüde yararlanılmıştır (Çetin, 2018, s. 10). Ancak Kırım Savaşı Osmanlı maliyesine altından kalkamayacağı ölçüde büyük bir yük getirmiştir (Dikmen, 2005, s. 139). Daha Kırım Savaş1 öncesinde Osmanlı İmparatorluğu'nun Galata Bankerlerine olan borcu 16 milyon liraya yükselmiştir. Savaş başladığında Osmanlı İmparatorluğu'nun bütçesi 7.5 milyon lira iken savaş masraflarının 18 milyon lira olacağı hesaplanmıştır (Özdemir, 2009, s. 45). Bu nedenle Osmanlı İmparatorluğu 24 Ağustos 1854 tarihinde yaptığı antlaşma ile Palmer \& Co ve Gold Schmit et Ass. şirketlerinden 3.3 milyon Osmanlı lirası borç almıştır (Aysal, 2013, s. 6). Böylece hızla artacak olan dış borç macerası başlamıştır.

Kırım Savaşı sonrasında bir yandan yeni dış borçlar alınırken diğer yandan Avrupa sermayesi Osmanlı topraklarına pek çok yatırım yapmaya başlamıştır. Alınan borçlar yüksek faiz ve giderle alınmış, verimli olarak kullanılmamış ve böylece borç yükü gittikçe artmıştır (Ünlüönen, 1988, s. 315). 1854-1874 yılları arasında imparatorluk $15 \mathrm{kez}$ borç almıştır. 1865 yılından itibaren alınan borçların miktarı gittikçe yükselmiştir (Yıldırım, 2001, s. 319). Alınan borçlar savaş giderleri, saray masrafları, saray inşası, donanma yapımı ve maaş ödemeleri gibi alanlarda kullanıldığı için borçlar ödemeleri yeni borç alınarak yapılmıştır (Kurnaz, 1989, s. 64). Borçların ödemeleri için yeni borçlar alınması da toplam borcun hızla arttırmıştır (Sayar, 1977, s. 191). 1874 y1lına gelindiğinde Osmanlı devlet bütçesi 25.104.958 lira iken ödenmesi gereken borç taksiti 30 milyon liraya ulaşmıştır (Fişek, 1967, s. 160). 1875 yılında artık borçların taksitleri ödenemez hale gelmiştir. Osmanlı İmparatorluğu 6 Ekim 1875 tarihinde iç ve dış borçların taksit ödemelerini 5 yıl süreyle yarıya düşürdügünü duyurmuştur. Kalan borç ödemeleri için hisse senedi basılacağını ilan etmiştir (Arslan, 2015, s. 4). Ancak bunu bile ödemeyi başaramamıştır (Aysal, 2013, s. 6). Bu nedenle 1876 yılında moratoryum ilan etmek zorunda kalmış ve bütün ödemeleri durdurmuştur (Pamuk, 1984, s. 56). Bu karar Avrupa kamuoyunu Osmanlı aleyhine çevirmiştir. 93 Harbi sırasında Osmanlı İmparatorluğu'nun Rusya karşısında yalnız kalmasında bu durum da önemli bir faktör olmuştur.

Osmanlı yönetimi 1879 yılında Galata Bankerleri ve Osmanlı Bankası ile bir antlaşma imzalamıştır. Bu antlaşma ile imparatorluk borçlarını 10 yıl içinde ödemeyi taahhüt etmiştir. Alacaklı devletler antlaşmayı protesto etmişlerdir (Afyoncu, 2001, s. 19). Bunun üzerine Osmanlı idaresi bu devletleri de borçları yeniden yapılandırmak için görüşmeye davet etmiştir. Yapılan görüşmeler neticesinde Osmanlı İmparatorluğu ve alacaklı devletlerin temsilcilerinin yer aldığı bir Duyun-u Umumiye (Genel Borçlar) İdaresi kurulmasına karar verilmiştir (Arslan, 2015, s. 5). Osmanlı Hükümeti 20 Aralık 1881 günü ilan ettiği kararname ile Duyun-u Umumiye İdaresi tesis edilmesini onaylamıştır (Aşç1, 2016, s. 1651).

Duyun-u Umumiye İdaresi Osmanlı İmparatorluğu'nun bütün iç ve dış ödemelerini üstlenmiştir (Gürsoy, 1984, s. 20). Yönetiminde 2 Türk ile 5 yabancı üye yer alan kuruluş taşrada örgütlenerek devletin gelirlerini toplamaya başlamıştır. Duyun-u Umumiye İdaresi özellikle vergi gelirlerinden elde ettiği parayı borç ödemelerinde kullanmakla görevlendirilmiştir (Önsoy, 1999, s. 145). Böylece idare 
tuz, alkol, pul, balıkçılık ve tütün gibi önemli vergi gelirlerinin denetimine sahip olmuştur. Duyun-u Umumiye'nin Osmanlı İmparatorluğu'nun belirlediği bazı vergileri toplayıp borç ödemelerinde kullanması karşı1lı̆ında imparatorluğun dış borcu 219 milyondan 125 milyon liraya düşürülmüştür (Arslan, 2015, s. 5).

İmparatorluk Duyun-u Umumiye sonrasında beş yıl boyunca borç almadan idare etmiştir. Ancak 1886 yılında Osmanlı Hükümeti yeniden dış borç almak zorunda kalmıştır (Açba, 1995, s. 108). Böylece imparatorluğun sonuna kadar sürecek olan borçlanma yeniden başlamıştır. Kapitülasyonların varlığı ve artan dış sermaye yatırımları ile beraber Osmanlı İmparatorluğu'nun dışa bağımlılı̆̆ 1 gittikçe artmıştır (Keskinkılıç, 2002, s. 378). Duyun-u Umumiye devletin vergi gelirlerinin büyük bir kısmını toplayan fakat hükümete bağlı olmayan bir yapı olarak daha çok alacaklılara hizmet etmiştir. Bu nedenle Osmanlı İmparatorluğu açısından oldukça zararlı bir gelişme olarak değerlendirilebilir (Kartopu, 2012, s. 37). Trablusgarp Savaşı sırasında İtalya Duyun-u Umumiye İdaresi'nden para almaya devam etmiştir. Bir bakıma Osmanlı topraklarından toplanan vergiler Trablusgarp'ta savaşan İtalya'nın savaşı finanse etmesinde kullanılmıştır (Kartopu, 2012, s. 37).

Duyun-u Umumiye İdaresi Osmanlı İmparatorluğu'nun borçlanmasına engel olmamıştır. 1914 yılına kadar $41 \mathrm{kez}$ dış borç alınmış ve toplam borç miktarı 104.212.000 liraya ulaşmıştır. Bu dönemde Osmanlı bütçesi 30 milyon lirayken yıllık borç taksiti 13 milyon lira olmuştur. Bütçenin neredeyse yarısı borç ödemelerine ayrılmıştır. Birinci Dünya Savaşı ile birlikte Osmanlı İmparatorluğu Almanya'dan büyük miktarda borç almaya başlamıştır. Duyun-u Umumiye savaş sırasında müttefik ülkelere ödeme yapmaya devam etmiş ancak düşman ülkelere yapılan ödemeleri durdurmuştur (Kutluönen, 1988, s. 316). Birinci Dünya Savaşı Osmanlı İmparatorluğu'nun borç yükünü oldukça arttırmıştır. Savaş boyunca alınan borç miktarı 150 milyon lirayı bulmuştur (Aysal, 2013, s. 8).

Birinci Dünya Savaşı sonrasında yapın Sevr Antlaşması ile Osmanlı İmparatorluğu hem borçlarını ödemek hem de savaş sırasında müttefiklere verdiği zararı telafi etmek için mali bir komisyon kurulmasını kabul etmiş̧tir. Duyun-u Umumiye'nin de aynen devam etmesine karar verilmiştir. Duyunu Umumiye dışında kalan gelirlerin ve Osmanlı bütçesinin bu komisyon tarafından denetlenmesi öngörülmüştür. İmparatorluğun yeni borç alması da komisyonun iznine bağlanmıştır (Aysal, 2013, s. 12).

Mustafa Kemal Paşa liderliğindeki Millî Mücadele’nin büyük bir zaferle sonuçlanması üzerine Sevr Antlaşması'nın hükmü kalmamıştır. Türkiye ile İtilaf Devletleri arasında barışı tesis etmek için Lozan Konferansı başlamıştır. Lozan Konferansı'nda borçlar konusunda pek çok tartışma yaşanmıştır. Türk heyeti Osmanlı borçlarının Balkan Savaşları'ndan itibaren imparatorluktan ayrılan ülkeler arasında paylaştırılmasını savunmuştur (Meray, 1971, s. 6). Buna karşın İtilaf Devletleri Osmanlı İmparatorluğu'ndan kalan borçları sadece Türkiye Cumhuriyeti'nin ödemesini talep etmişlerdir. Yapılan görüşmeler sonucunda bu konuda uzlaşma sağlanmış ancak borçlar adil olmayan bir şekilde pay edilmiştir. Lozan Antlaşması'nda yer alan 46. madde ile Türkiye borçların kendisine düşen kısmını ödemeyi kabul etmiştir. Lozan Antlaşması ile Duyun-u Umumiye de kaldırılmıştır (Gürsoy, 1984, s. 21). Borçların ödenmesinde kullanılacak para biriminin belirlenmesi daha sonraya bırakılmıştır (Aysal, 2013, s. 19). Daha sonra yapılan görüşmelerde ödeme birimi konusunda anlaşmazlık yaşanmıştır. Türkiye ödemeleri lira veya frank olarak yapmak istemiş karşı taraf ise altın veya sterlinde ısrar etmiştir. Bu nedenle mesele 1928 yılına kadar uzamıştır (Aşçı, 2016, s. 1651).

Osmanlı döneminden kalan borçlar Türkiye Cumhuriyeti'nin kalkınma politikasını baltalamıştır. Cumhuriyet sanayileşme politikasının yanı sıra borç ödemelerini de gerçekleştirmek zorunda kalmıştır. Borçların ödemesinin 1954 yılında tamamlandığı göz önüne alındığında bu durum kolayca anlaşılmaktadır (Dikmen, 2005, s. 151).

\section{2.İngiltere Lordlar Kamarası'ndaki oturum ve değerlendirme}

21 Mayıs 1924 günü Lordlar Kamarası'nda Osmanlı İmparatorluğu'nda kalan borçların durumunu tartışmak üzere bir oturum yapılmıştır. Oturuma Lord Banbury of Southam'ın hükümete sorduğu sorularla başlanmıştır. Lord Banbury ilk olarak İngiliz Ordusu Irak ve Filistin'i işgal ettikten sonra İngiliz Hükümeti'nin orada bulunan Duyun-u Umumiye İdaresi hazinesine el koyup koymadığını ve 1918-1920 yılları arasında bölgedeki tahvil sahiplerine gelirlerinin ödenip ödenmediğini sormuştur. İkinci olarak Balkan Savaşlarında ve Rusya karşısında elden çıkan Türk topraklarında tahvili bulunan 
hak sahiplerine ait gelirler hakkında İngiliz Hükümeti'nin bir girişimde bulunup bulunmadığını öğrenmek istemiştir. Ayrıca Fransız Hükümeti'nin Suriye'yi işgal ettikten sonra oradaki hak sahiplerinin gelirlerini ödeyip ödemediğini ve İngiliz Hükümeti'nin şu ana kadarki davranışının 1907 Lahey Sözleşmesi'nin 46. maddesine ve uluslararası hukuka aykırı olup olmadığını sormuştur. Lord Banbury son olarak Türk Hükümeti'nin, 1881 ve 1903 yılında yapılan antlaşmalara ve Berlin Antlaşması'nı imzalayan devletlere rağmen, tahvil sahiplerinin haklarını fiilen ihlal edip etmediğini öğrenmek istemiştir (İngiltere Parlamento Arşivi, 1924, s. 545).

Osmanlı İmparatorluğu'nun borçları üzerinden kar eden Avrupalı yatırımcılar Birinci Dünya Savaşı ile beraber gelir kaybına uğramışlardır. İngiliz Ordusu tarafından işgal edilen topraklarda Duyunu Umumiye gelirlerine İngiltere tarafindan el koyulması tahvil sahiplerine yapılan ödemelerin durmasına yol açmıştır. Osmanlı İmparatorluğu da savaş içinde olduğu devletlere yaptığı borç ödemelerini durdurmuş̧tur. Bu durum tahvil sahiplerinin tepki göstermesine yol açmıştır. Savaş sonrasında tahvil sahipleri savaş sırasında ertelenen ödemelerini elde etmek için yoğun çaba göstermişlerdir. Lord Banbury'nin sorduğu sorular bu kapsamda değerlendirilmelidir.

Lord Banbury konuşmasının devamında birkaç yıl önce Türk Hükümeti’nin temerrüde düştüğü için bazı gelirlerini tahvil sahiplerine vermeyi vaat ettiğini hatırlatmıştır. Osmanlı gelirlerinin Birinci Dünya Savaşı'na kadar Duyun-u Umumiye tarafından toplandığını, bu nedenle Irak ve Filistin'de de Duyun-u Umumiye idaresinin elinde belli bir miktar para olduğunu dile getirmiştir. İngiltere'nin Irak ve Filistin'i işgali sonrasında İngiliz Hükümeti'nin bu paralara el koyduğunu ve tahvil sahiplerine yapılan ödemeleri askıya aldığını belirtmiştir. Daha sonra ise bu paraların tahvil sahiplerine değil Irak ve Filistin Hükümetlerine iade edildiğini hatırlatmıştır. $\mathrm{Bu}$ nedenle Türkiye Cumhuriyeti'nin Duyun-u Umumiye'yi tanımadığını ve bunu Lozan Antlaşması ile hukuki hale getirdiğini söylemiştir (İngiltere Parlamento Arşivi, 1924, s. 546-547).

Tahvil sahipleri Birinci Dünya Savaşı'nda Irak ve Filistin'den alacaklarına el koyan İngiliz Hükümeti'nden savaş sonrasında alacaklarını talep etmişlerdir. Ancak İngiliz Hükümeti geçmişe dönük ödeme yapmaya pek sıcak bakmamıştır. Tahvil sahipleri paralarının teminatı olan Duyun-u Umumiye İdaresi'nin kaldırılmasından ve Lozan Antlaşması ile getirilen yeni düzenden endişe etmişlerdir. Bu nedenle Lozan Antlaşması'nı tepki ile karşlamışlardır. Ancak tahvil sahiplerinin girişimleri hükümet politikasını değiştirmeye yetmemiştir. Bu konunun Lordlar Kamarası'nda tartışılması ve Avam Kamarası'nda gündeme gelmemesi İngiliz Hükümeti'nin tavrından kaynaklanmıştır.

Lord Banbury, üyesi olduğu Yabanc1 Tahvil Sahipleri Konseyi’nin İngiliz tahvil sahiplerinin haklarını korumak için hareket ettiğini belirtmiştir. Konseyin 19 Aralık günü İngiliz Hükümeti'ne gönderdiği yazıda şunları hatırlattığını ifade etmiştir: "Osmanlı Hükümeti 1881 yılında imzaladığı kararname ile tüm borçlar ödenene kadar bütün Osmanlı topraklarında gelirlerin toplanması hakkını uluslararası bir komisyona bırakmıştır. Bu komisyon elde edilecek gelirlerden tahvil sahiplerine gereken ödemeleri yapacaktır." Lord Banbury, Türkiye'nin parçalanması sonrasında imzalanan Lozan Antlaşması nedeniyle durumda bazı düzenlemeler yapıldığını hatırlatmıştır. Antlaşma ile Osmanlı borçlarının 1912 yılından itibaren imparatorluktan kopan toprakları ele geçiren ülkeler ile Türkiye arasında paylaştırıldığını ifade etmiştir. İngiliz Hükümeti'nin Irak ve Filistin'de toplanan paraları aldığını ve sahiplerine değil başka kişilere iade ettiğini bir kez daha vurgulamıştır. Lozan Konferansı'nda İtilaf Devletleri'nin 1 Mart 1920 tarihinden itibaren Türkiye sınırları dışında kalan yerlerin borçlarından Türkiye Cumhuriyeti'nin sorumlu tutulmamasını önerdiklerini, Türk delegasyonunun ise 30 Ekim 1918 tarihi sonrasında Osmanlı sınırları dışında kalan yerlerin borçlarını üstlenmeyi kabul etmediklerini hatırlatmıştır. Irak, Suriye ve Filistin'de 1 Mart 1920 sonrasında alacaklılara tahvil ödemelerini yeni kurulan yönetimlerin yapmasına karar verildiğini ifade etmiştir. $\mathrm{Bu}$ nedenle İngiliz ve Fransız Hükümetlerinin alacaklılara ödeme yapması gerektiğini savunmuştur. Lozan Antlaşması'nın onaylandığını bu yüzden Türkiye dışında kalan topraklardan Türk Hükümeti'nin sorumlu tutulamayacağını dile getirmiştir (İngiltere Parlamento Arşivi, 1924, s. 547-549).

Osmanlı Hükümeti'nden bağımsız hareket eden Duyun-u Umumiye yabancı alacaklıların paralarını tahsil etmelerini garanti altına almıştır. Bu nedenle İngiliz tahvil sahipleri Duyun-u Umumiye'nin kaldırılmasından son derece rahatsız olmuşlardır. Lozan Antlaşması ile İngiliz Hükümeti'nin bunu kabul etmesi tahvil sahipleri tarafindan eleştirilmektedir. İngiliz Hükümeti'nin Irak, 
Suriye ve Filistin'de Duyun-u Umumiye hazinesine el koyduğunu, daha sonra bu paraları bölgedeki yönetimlere ödeyerek tahvil sahiplerinin zarara uğrattığını savunmaktadırlar.

Lord Banbury alacaklıların İngiliz Hükümeti’nin yaptığı açıklamalardan tatmin olmadıklarını ve paralarını istediklerini söylemiştir. Bağdat'ın 1917 yılında İngiltere tarafından ele geçirildiğini ve mali yönetime İngiliz makamlar tarafından el konulduğunu hatırlatmıştır. Bundan sonra 35.000 pound alması gereken tahvil sahiplerine 23.000 pound önerildiğini belirtmiştir. Bu durumun Avrupa'daki diğer ülkeler için çok kötü bir örnek teşkil edeceğini ileri sürmüştür. Bu tarihten itibaren kişilerin diğer ülkelerde borç tahvili almalarının imkansız hale geleceğini savunmuştur (İngiltere Parlamento Arşivi, 1924, s. 549-550).

Bu konuşma sonrasında Lord Sydney Arnold söz almıştır. İngiliz Ordusu Mezopotamya’ya girdikten sonra İngiliz Hükümeti'nin Duyun-u Umumiye görevlilerini mümkün olduğunca yerinde tuttuğunu ve gelir hesaplarını aynı şekilde tutmaya devam ettiğini iddia etmiş̧ir. İstanbul müttefik alacaklılara ödeme yapmayı sürdürüp düşmanlara ödeme yapmayı kestiği için bölgedeki gelirlerin İstanbul'daki Duyun-u Umumiye genel merkezine gönderilmediğini dile getirmiştir. Lord Arnold konuşmasında, bölge Osmanlı İmparatorluğu'na iade edilmeyeceği için gelirlerin toplanması için yeni bir düzenleme yapıldığını hatırlatmıştır. 1920 yılına kadar böyle devam edildiğini belirtmiştir. Savaş sonrasında Sevr Barış Antlaşması ile yeni bir düzenleme daha yapıldığını ancak antlaşmanın uygulanmaya koyulamadığını ifade etmiştir. Kalıcı çözümün Lozan Antlaşması ile birlikte sağlandığını antlaşmanın Türkiye Büyük Millet Meclisi tarafından onaylandığını ve yakında müttefikler tarafından da onaylanacağını belirtmiştir. Bu antlaşma ile Balkan Savaşları ve Birinci Dünya Savaşı sırasında Osmanlı İmparatorluğu'ndan kopan ülkeler ile Türkiye Cumhuriyeti arasında savaş öncesinde Osmanlı'dan kalan borçların paylaştırıldığını hatırlatmıştır. Lozan Konferansı'nda borçlar hakkında birçok tartı̧̧ma yaşandığını anımsatmıştır. Bazı çevrelerin tüm borcun Türkiye tarafından üstlenilmesini önerdiklerini ancak bu fikrin kabul görmediğini dile getirmiştir. Daha sonra Osmanlı İmparatorluğu'ndan ayrılan devletlerin hangi tarihten itibaren başlayan borçlardan sorumlu olacakları konusunda tartışma yaşandığını ifade etmiştir (İngiltere Parlamento Arşivi, 1924, s. 550-551).

Osmanlı İmparatorluğu savaşa girdikten sonra Duyun-u Umumiye Osmanlı İmparatorluğu ile ittifak içinde olan ülkelere ödeme yapmaya devam etmiştir. Fakat imparatorlukla savaş içerisinde olan ülkelere yapılan ödemeler durdurulmuştur. İngiliz Hükümeti Sevr Antlaşması ile bunun intikamını almıştır. Ancak Milli Mücadele'nin başlaması Sevr Antlaşması'nın uygulanmasını engellemiştir. Milli Mücadele'nin başarıya ulaşması sonrasında imzalanan Lozan Antlaşması ile barış sağlanmıştır. Bu durumun bozulmasını istemeyen İngiliz Hükümeti tahvil sahiplerine ellerindekine razı olmalarını tavsiye etmiştir.

Lord Banbury Yabancı Tahvil Sahipleri Konseyi'nin Dışişleri Bakanlığı'na başvurarak Anadolu'da 1 Mart 1920 tarihine kadar işgal altında olan bölgelerden toplanan gelirlerden kendisine ödeme yapılmasını talep ettiğini hatırlatmıştır. Savaş öncesi borçların yeniden paylaştırılması mümkün olmadığı için Konseyin önerisinin reddedildiğini açıklamıştır. Irak ve Filistin Hükümetlerinin savaş öncesi borçlardan kendilerine verilen pay dışında ekstra bir yükümlülüğü kabul etmeyeceklerini belirtmiştir. Hükümetin yıllarca süren mücadele ve çetin müzakereler sonucunda imzalanan Lozan Antlaşması'nda vazgeçemeyeceğini ve bundan dolayı borçlar konusunda yeni bir düzenleme yapamayacağını ifade etmiştir. Zaten savaş öncesi borçlardan aldıkları pay nedeniyle Irak ve Filistin Hükümetlerinin büyük bir sıkıntı içinde olduklarını yeni bir yükü kesinlikle kabul etmeyeceklerini 1srarla vurgulamıştır. Lozan Antlaşması ile yapılan düzenlemenin tahvil sahipleri açısından avantajlı bir durum yarattığını ileri sürmüştür. Osmanlı İmparatorluğu'nun Türkiye ile imparatorluktan kopan diğer devletler arasında bölüştürülmesinin önemli bir gelişme olduğunu ifade etmiştir. Bu durumun tahvil sahiplerine büyük bir güvence sağladığını savunmuştur (İngiltere Parlamento Arşivi, 1924, s. 552).

Mevcut şartlarda Lozan Antlaşması'ndan daha iyi bir antlaşma yapamayacağını düşünen İngiliz Hükümeti tahvil sahiplerinin istekleri uğruna barışı tehlikeye atmak istememiştir. İngiliz Hükümeti ayrıca himayesi altında kurulan Irak ve Filistin yönetimlerinin borç yükü altına girmek istemeyeceklerini de fark etmiştir.

Lord Banbury Duyun-u Umumiye İdaresi'nin Türk Hükümeti tarafından ortadan kaldırılıp kaldırılmadığını sormuştur. Lord Arnold bu soruya daha sonra cevap vereceğini ve Lord Banbury'nin 
antlaşmadan memnun olmadığını fark ettiğini söylemiştir. İngiliz Hükümeti’nin birkaç yıldır Türkiye'deki durum nedeniyle büyük meblağlar harcadığını hatırlatarak, tahvil sahipleri daha fazla kar etsin diye hükümetin antlaşmayı bir kenara iterek yeni masraflara yol açmak istemediğini ifade etmiştir. Lozan Konferansı sırasında yapılan görüşmelerde Yabanc1 Tahvil Sahipleri Konseyi üyelerinin de olduğunu söyleyerek, bu üyelerin antlaşma ile getirilen düzene itiraz etmediklerini dile getirmiş̧ir (İngiltere Parlamento Arşivi, 1924, s. 553).

İngiliz Hükümeti'nin, tahvil sahiplerinin istekleri nedeniyle barışı riske atmaya niyetli olmadığı burada bir kez daha göze çarpmaktadır.

Lord Arnold 1912 y1lına kadar İngiliz Hükümeti’nin İngiliz tahvil sahiplerini her zaman desteklediğini ifade etmiştir. Balkan Savaşlarına rağmen bu politikanın devam ettiğini ancak Birinci Dünya Savaş1 ile birlikte değişim yaşandığını belirtmiş̧ir. Lord Arnold, İngiltere'nin işgal ettiği Osmanlı topraklarında gelirlere el koyduğunu ve Duyun'u Umumiye merkezine göndermediğini hatıllatmıştır. Ödeme yapılması durumunda paranın düşmanın ellerine teslim edileceğini ifade etmiştir (İngiltere Parlamento Arşivi, 1924, s. 554).

İngiltere Irak ve Filistin'i ele geçirdikten sonra bölgedeki gelirlere el koyarak savaş için kullanmıştır. Osmanlı borçları üzerinden gelir elde eden tahvil sahipleri bu durumdan zarar etmişlerdir. Bu mesele İngiltere de sık sık tartışma yaratmıştır.

Lord Arnold, Ankara Hükümeti'nin Duyun-u Umumiye'yi ortadan kaldırdığını, Muharrem Kararnamesini ve 1903 yılında hazırlanan kararnameyi tanımadığını ifade etmiştir. İngiliz Maliye Bakanı'nın 5 Mayıs günü yaptığı açıklamada bu durumun Lozan Antlaşması'na uygun olmadığını söylediğini hatırlatmıştır. Lord Arnold Muharrem ve 1903 kararnameleriyle Osmanlı gelirlerinin Duyun-u Umumiye'ye bırakıldığını ancak 1920 yılında Ankara Hükümeti'nin kontrolü altındaki topraklarda bu duruma son verdiğini ifade etmiştir. Lord Arnold ayrıca Duyun-u Umumiye'nin bu durumu protesto ettiğini ancak bir sonuç alamadığını dile getirmiştir. Birkaç hafta önce Türk Hükümeti'nin İstanbul ve çevresindeki Duyun-u Umumiye şubelerine de son verdiğini belirtmiştir. Şu anda İngiliz Hükümeti'nin duruma müdahil olmadığını ancak diğer devletlerin tutumuna göre tavır alacağını bildiğini söylemiştir. Lord Banbury İngiliz Hükümeti'nin diğer devletler ile birlikte tahvil sahiplerinin haklarını korumak için harekete geçip geçmeyeceğini sormuştur. Lord Arnold Duyun-u Umumiye'nin kendi temsilcileri olduğunu ve gerekli görüşmeleri yapacağını ifade etmiştir. İngiliz Hükümeti'nin izleyeceği politika hakkında konuşmak için henüz erken olduğunu da dile getirmiştir (İngiltere Parlamento Arşivi, 1924, s. 555).

Lord Arnold'un ifadelerinden İngiliz Hükümeti'nin Duyun-u Umumiye ve borçlar meselesini uluslararası bir sorun olarak gördüğ̈̈ açıkça anlaşılmaktadır. Lord Arnold İngiliz Hükümeti'nin tek başına hareket etmeyeceğini açıklamaktan çekinmemiştir. Sorunun başka ülkeleri de ilgilendirdiğini ifade ederek eleştirilerden kaçınmak istemektedir.

\section{Sonuç}

Lozan Antlaşması ile kapitülasyonlar, Duyun-u Umumiye İdaresi ve Sevr Antlaşması'nda yer alan Mali Komisyon ortadan kaldırılmıştır. Bu durum Avrupalı alacaklıları endişelendirmiştir. Özellikle İngiltere'de Yabanc1 Tahvil Sahipleri Konseyi İngiliz Hükümeti üzerinde bask1 kurarak Duyun-u Umumiye İdaresi'nin devam ettirilmesi için girişimde bulunulmasını istemiştir. Konsey ayrıca Lozan Antlaşması ile getirilen düzenin değiştirilmesi gerektiğini de savunmuştur. Yaşanan bu itirazlar Lozan Antlaşması'nın İngiliz Parlamentosu'nda onaylanmasını geciktiren nedenlerden biri olarak kabul edilebilir.

Buna karşılık İngiliz Hükümeti mevcut düzenin tahvil sahiplerini zarara uğratmadığını dile getirerek mevcut düzeni savunmuştur. İngiliz Hükümeti Lozan Antlaşması'nın çok zorlu bir süreç sonucunda imzalandığını, borç ödemeleri yüzünden barışın tehlikeye atılamayacağını ısrarla vurgulamıştır. Bu oturumdan kısa bir süre sonra İngiliz Parlamentosu Lozan Antlaşması'nı onaylamıştır.

Yabancı Tahvil Sahipleri Konseyi ile İngiliz Hükümeti arasında, Birinci Dünya Savaşı sırasında İngiliz Ordusu'nun işgal ettiği Osmanlı topraklarına ait gelirler konusunda da anlaşmazlık yaşanmıştır. Konsey 1916-1918 yıllarına ait gelirlerin borç alacaklılarına ödenmesi gerektiğini savunmuş ancak İngiliz Hükümeti geçmişe dönük bir ödeme yapmaya yanaşmamıştır. Konseyin girişimlerine rağmen bu 
Osmanlı borçları hakkında İngiliz Lordlar Kamarası'nda yapılan 21 Mayıs 1924 tarihli oturumun incelemesi, Ç., YÜKSEL

mesele Avam Kamarası'nda pek gündeme gelmemiş ancak Lordlar Kamarası'nda tartış1labilmiştir. Bu olay İngiliz Hükümeti’nin konunun üstünü örtmek istediği veya politikasında bir değişiklik yapmak istemediği şeklinde yorumlanabilir. 
Kayseri Üniversitesi Sosyal Bilimler Dergisi, Cilt 2, Sayı: 2, Aralık 2020, 123-133

Kayseri University Journal of Social Sciences, Vol 2, No: 2, December 2020, 123-133

\section{NOTLAR}

1-İngiltere Parlamento tutanaklarına "www.hansard.millbanksystems.com" adresinden ulaş1labilmektedir.

2-Lord Banbury of Southam: Frederick Banbury 1850-1936 yılları arasında yaşamış İngiliz iş adamı ve siyasetçidir. Siyasi yaşamını Muhafazakâr Parti'de geçirmiştir. 1924 yılından itibaren İngiltere Lordlar Kamarası üyesi olmuş ve bu görevi hayatının sonuna kadar sürdürmüştür.

3-Lord Arnold: Baron Sydney Arnold 1878-1945 yılları arasında yaşamıș İngiliz siyasetçidir. Siyasi yaşamına Liberal Parti'de başlamıştır. 1922 yılında İşçi Partisi'ne katılııştır. 1924 yılından itibaren İngiltere Lordlar Kamarası'nda yer almaya başlamıştır. 
Osmanlı borçları hakkında İngiliz Lordlar Kamarası'nda yapılan 21 Mayıs 1924 tarihli oturumun incelemesi, Ç., YÜKSEL

\section{KAYNAKÇA}

Acar, K. (2019). Kırım Savaşı (1853-1856) döneminde propaganda: Rus popüler kültüründe savaş ve düşman imgesi. Bilig, 88, 113-136.

Açba, S. (1995). Osmanlı Devleti'nin dış borçlanması. Afyon Kocatepe Üniversitesi Yayınları.

Afyoncu, E. (2001). 100 soruda Osmanlı borçlanı. Popüler Tarih, 13,17-21.

Arslan, G. (2015). Osmanlı Devleti'nin dış borçları ve yeniden yapılandırma süreci (1930-1933). History Studies. 7(4), 1-23.

Aşçı, H. (2016). Lozan Barış Antlaşması'nda Osmanlı Borçları Meselesi. İnsan ve Toplum Bilimleri Araştırmaları Dergisi, 5(6), 1649-1666.

Aysal, N. (2013). Kırım Savaşı’nda Lozan Barış Antlaşması'na Osmanlı dış borçlarının tarihsel gelişimi. Atatürk Yolu Dergisi, 14(53), 1-28.

Birbudak, T. (2018). 1853-1856 Kırım Harbi’nde Osmanl1-Avusturya ilişkileri. Belleten, 82(293), 241264.

Çetin, M. ve Kök, R. (2018). Kırım Savaşı örneğinde Osmanlı ordusunda gayrimüslimlerin istihdamı. Bilig, 85, 1-24.

Dikmen, N. (2005). Osmanlı Borçlarının ekonomik ve siyasi sonuçları. Atatürk Üniversitesi İktisadi ve İdari Bilimler Dergisi, 19(2), 137-159.

Ergüder, B. (2020). Duyun-u Umumiye İdaresi'nin borç yönetiminden bir kesit: İkramiyeli tahviller. Tarih ve Gelecek Dergisi, 6(2), 470-485.

Fişek, K. (1967). Osmanlı borçları üzerine düşünceler. Ankara Üniversitesi SBF Dergisi, 22(3), 157 164.

Gürsoy, B. (1984). 100. yılında Duyun-u Umumiye İdaresi üzerine bir değerlendirme. İstanbul Üniversitesi Iktisat Fakültesi Mecmuası, 40(1-4), 17-59.

İngiltere parlamento tutanakları (1924, 21 Mayıs). Lordlar Kamarası. Ottoman Public Dept: Bondholders' Rights, 57, 545-556.

Karamursal, Z. (1989). Osmanl mali tarihi hakkında tetkikler. Türk Tarih Kurumu Yayınları.

Kartopu, S. (2012). Duyun-u Umumiye İdaresi ve idareyle ilgili görüşler. Global Journal of Economics and Business Studies. 1(2), 32-40.

Kazgan, G. (1999). Tanzimat'tan. Yüzyıla Türkiye ekonomisi. Altın Yayınları.

Keskinkılıç, E. (2002). Duyun-u Umumiye İdaresi. Türkler, (Cilt 14, ss. 371-380). Yeni Türkiye Yayınları.

Kodaman, B. (2007). Osmanlı Devleti'nin yükseliş ve çöküş sebeplerine genel bakış. Süleyman Demirel Üniversitesi Fen-Edebiyat Fakültesi Sosyal Bilimler Dergisi, 16, 1-24.

Kurnaz, Ş. (1989). Osmanlı borçları (1854-1954). Milli Ĕgitim Dergisi, 90, 63-73.

Küçük, C., \& Ertüzün, T. (1994). Duyun-1 Umumiye. İslam Ansiklopedisi. (Cilt. 10, ss. 58-62). Türkiye Diyanet Vakfı Yayınları.

Meray, S. (1971). Lozan Barış Konferansı- tutanaklar belgeler. C. 3, Ankara Üniversitesi Siyasal Bilgiler Fakültesi Yayınları.

Müderrisoğlu, A. (1990). Kurtuluş Savaşı'nın mali kaynakları. Atatürk Araştırma Merkezi Yayınları.

Önsoy, R. (1999). Mali tutsaklı̆̆a giden yol Osmanlı borçları (1854-1914). Turhan Kitabevi.

Özdemir, B. (2009). Osmanlı Devleti dış borçları. Ankara Ticaret Odası Yayınları.

Pamuk, Ş, (1984). Osmanlı Ekonomisi ve dünya kapitalizmi. Yurt Yayınları.

Pamuk, Ş. (1999). Osmanlı Imparatorluğu'nda paranın tarihi. Türkiye Tarih Vakfı Yurt Yayınları. 
Kayseri Üniversitesi Sosyal Bilimler Dergisi, Cilt 2, Sayı: 2, Aralık 2020, 123-133

Kayseri University Journal of Social Sciences, Vol 2, No: 2, December 2020, 123-133

Sayar, N. (1977). Türkiye imparatorluk dönemi mali olayları. Met-Er Matbaas1.

Ünlüönen, K. (1988). Cumhuriyet Dönemi borçları. Dicle Üniversitesi Hukuk Fakültesi Dergisi, 4(4), 313-335.

Yıldırım, İ. (2001). On dokuzuncu yüzyıl Osmanlı ekonomisi üzerine bir değerlendirme (1838-1918). Firat Üniversitesi Sosyal Bilimler Dergisi, 11(2), 313-326.

Yıldız, A. (2011). Osmanlı Devleti'nin borçlanmasında Osmanlı Bankası'nın rolü ve önemi. Elektronik Sosyal Bilimler Dergisi, 10(36), 318-330.

Yılmaz, B. (2002). Osmanlı İmparatorluğu'nu dış borçlanmaya iten nedenler ve ilk dış borç. Akdeniz Üniversitesi İktisadi ve İdari Bilimler Fakültesi Dergisi, 4, 186-198. 